\title{
PENGARUH AKTIVITAS FISIK MAKSIMAL DAN EKSTRAK DAUN BAMBU MANGGONG (Gigantochloa manggong) TERHADAP AKTIVITAS KATALASE PADA HATI TIKUS PUTIH (Rattus norvegicus)
}

\author{
Ririen Apriana, Supriyatin \& Sri Rahayu \\ Jurusan Biologi FMIPA Universitas Negeri Jakarta (UNJ). Jl. Pemuda No. 10 Rawamangun, Jakarta Timur. \\ 13220. Indonesia. \\ Email: ririenapriana@ymail.com
}

\begin{abstract}
Gigantochloa manggong, one of endemic bamboo plant in Indonesia is suspected have potensial as an exogenous antioxidant. Exogenous antioxidant can help the activity of endogenous antioxidant on the body when overtraining occurs. Antioxidant can be measured by catalase enzymes activity. This present study was carried out to determine the effect of maximum physical activity and leaf bamboo extract on catalase activity in liver organ of rats. This research used experimental method with completely randomized design (CRD). The test groups were the control rats (E0R0), rats induced leaf extract (E1R0), rats treated swimming activity (EOR1) and rats induced leaf extract and swimming activity (E1R1). Data were analyzed by the two-way ANOVA statistical test. Bamboo leaf extract turned out to be non-toxic and leaf extract contained flavonoids, alkaloids, triterpenoids dan saponins. Catalase units in the control group $=1.00 \mathrm{unit} / \mathrm{ml}$, the group which induced leaf extract $=0.89 \mathrm{unit} / \mathrm{ml}$, the group which treated maximum physical activity $=0.78 \mathrm{unit} / \mathrm{ml}$ and the group which treated maximum physical activity and induced leaf extract $=0.56$ unit/ $\mathrm{ml}$. Based on statistical test, catalase activity no effect $(p>0,05)$ on rats. It was concluded that maximum physical activity can't decreased catalase activity, leaf bamboo extract can't increased catalase activity and there was no effect between maximum physical activity and manggong bamboo leaf extract on catalase activity in liver organ of rats.
\end{abstract}

Keyword : antioxidant, catalase, manggong bamboo, physical activity

\section{PENDAHULUAN}

Dalam tubuh normal dapat terjadi pembentukan radikal bebas akibat metabolisme tubuh dan dapat diantisipasi oleh antioksidan endogen. Pada saat tubuh melakukan aktivitas secara berlebihan, radikal bebas pun meningkat dan antioksidan endogen tidak mampu secara penuh untuk menangkalnya maka diperlukan antioksidan eksogen. Antioksidan eksogen yang dihasilkan dari tumbuhan dapat mereduksi radikal bebas.

Pemanfaatan bambu saat ini belum maksimal hanya sebatas sebagai alat-alat untuk memenuhi kebutuhan sehari-hari. Pada penelitian yang dilakukan oleh Wang et al. (2012) diketahui bahwa daun bambu dengan genus Bambusa mengandung senyawa antioksidan berupa flavonoid, lakton, dan asam fenolat, sehingga kemungkinan pada bambu lain juga mengandung senyawa yang sama. Salah satu jenis bambu yang terdapat di Indonesia adalah bambu manggong (Gigantochloa manggong) yang merupakan tumbuhan endemik di wilayah Jawa Timur.

Aktivitas antioksidan dapat diukur dari jumlah katalase yang dihasilkan dalam tubuh. Saat tubuh mendapat aktivitas fisik yang berlebihan, kerja dari enzim katalase yang terdapat dalam tubuh menjadi meningkat. Adanya 
pemberian antioksidan eksogen dapat membantu kerja enzim katalase. Penelitian ini dilakukan untuk mengetahui aktivitas katalase sebagai parameter stres oksidatif pada hati tikus putih (Rattus norvegicus) yang diberi aktivitas fisik maksimal berupa renang dan ekstrak daun bambu manggong dan mengetahui pengaruh aktivitas fisik dan ekstrak pada aktivitas katalase hati tikus putih.

\section{BAHAN DAN METODE}

\section{Waktu dan Lokasi Penelitian}

\section{Prosedur Penelitian}

Penelitian ini telah lulus etik dengan nomor 279/H2.F1/ETIK/2014. Metode yang digunakan dalam penelitian ini adalah metode eksperimental dengan desain Rancangan Acak Lengkap (RAL) pola faktorial yang terdiri dari dua faktor (ekstrak daun bambu manggong dan aktivitas fisik maksimal). Kelompok yang diuji adalah tikus kontrol (E0R0), tikus yang diberi ekstrak daun (E1R0), tikus yang diberi aktivitas fisik maksimal berupa renang (E0R1) dan tikus yang diberi ekstrak daun dan aktivitas fisik maksimal (E1R1).

\section{a. Uji fitokimia}

Uji ini dilakukan untuk mengetahui kandungan senyawa sekunder dalam ekstrak daun bambu manggong. Daun diambil di Taman Nasional Meru Betiri Jawa Timur. Daun diekstrak dengan etanol 70\% dan diuji fitokimia dengan pengujian flavonoid, alkaloid, triterpenoid, saponin, fenolat dan tanin.

\section{b. Uji Toksisitas Akut}

Pengujian toksisitas bertujuan untuk menentukan dosis ekstrak daun bambu manggong. Dalam penelitian ini sebanyak 28 ekor tikus dibagi menjadi 7 kelompok dosis (4 tikus/kelompok), yaitu dosis 400, 800, 1250, 2500, 5000, 10000, dan $20000 \mathrm{mg} / \mathrm{kgBB}$.

\section{c. Uji Efek Aktivitas Fisik Maksimal dan Pemberian Ekstrak}

Ekstrak diberikan peroral pada tikus wistar satu kali sehari dengan dosis sebesar $400 \mathrm{mg} / \mathrm{kgBB}$ (Lin et al., 2012). Aktivitas fisik berupa renang diinduksi selama 3 x 5 menit dengan istirahat selama 15 menit (Herwana, 2005) selama sekali sehari dan dilakukan satu jam sebelum diberi ekstrak.

Pengukuran Aktivitas Katalase Pengukuran aktivitas katalase menggunakan metode spektrofotometri dengan mengukur absorbansi sampel dan blanko. Pada cuvet blanko dimasukkan $\mathrm{H} 2 \mathrm{O} 2$ yang telah diencerkan sebanyak $1900 \mu \mathrm{l}$ dan PBS 0.05 pH 7 sebanyak $100 \mu$ l. Pada cuvet sampel dimasukkan protein homogenat hati sebanyak 100 $\mu \mathrm{l} \mathrm{H} 2 \mathrm{O} 2$ yang telah diencerkan sebanyak $1900 \mu \mathrm{l}$. Serapan dicatat pada panjang gelombang $240 \mathrm{~nm}$ pada menit ke-1 (t0) sampai menit ke-2 (t1) (Anatreira, 2012) dengan rumus aktivitas katalase:

\section{ANALISIS DATA}

Data yang dikumpulkan adalah data kualitatif hasil uji fitokimia berupa gambar warna larutan dan data kuantitatif unit katalase yang dihitung dari nilai absorbansi menggunakan alat spektrofotometer dengan panjang gelombang $240 \mathrm{~nm}$. Data diuji dengan uji homogenitas (Uji Barttlet), uji normalitas (Uji Kolmogorov-Smirnov) dan ANAVA dua arah dengan $\alpha=0.5$.

\section{HASIL}

Pengaruh Pemberian Aktivitas Fisik Maksimal pada Aktivitas Katalase Hati Tikus Putih Tikus yang diberi 
aktivitas fisik maksimal berupa renang, memungkinkan kondisi tikus mengalami stres oksidatif yang berakibat pada penurunan berat badan. Dalam kondisi ini mengakibatkan terpicunya sekresi Corticotropin-releasing hormone (CRH) (Nagaraja, 2001) yang memiliki efek penekanan asupan makanan. Hormon CRH ini bekerja untuk merangsang kortisol yang berfungsi dalam katabolisme yaitu membongkar senyawa seperti karbohidrat sehingga mempengaruhi metabolisme dalam tubuh dan dapat berakibat pada penurunan berat badan. Sebaliknya, tikus yang mengalami kenaikan berat badan yaitu pada tikus tanpa perlakuan apapun (kontrol). Ini terjadi dikarenakan asupan makanan yang cukup serta tidak adanya tekanan atau kondisi tubuh tidak mengalami stres yang membuat

$$
\begin{aligned}
& \text { Keterangan: } \\
& \text { Katalase }(U / m l)=\frac{\Delta S-\Delta B}{m o l H_{2} O_{2} x V} \times \mathrm{F} \quad \text { absorbansi sampel }(\AA / \text { menit }) \\
& \mathrm{B}=\text { absorbansi blanko }(\AA / \text { menit }) \\
& \mathrm{Mol}=\text { molaritas } \mathrm{H}_{2} \mathrm{O}_{2}(\mathrm{mM}) \\
& \mathrm{V}=\text { volume sampel yang diukur }(\mu \mathrm{L}) \\
& \mathrm{F} \quad=\text { faktor pengenceran }
\end{aligned}
$$

pertumbuhan badan tikus meningkat atau tumbuh secara normal. Dalam keadaan normal, radikal bebas yang terdapat dalam tubuh dapat tetap terbentuk akibat adanya metabolisme yang kurang sempurna, maka dari itu enzim katalase membantu agar radikal bebas menjadi senyawa yang tidak reaktif. Kelompok tikus yang mengalami stres akibat aktivitas fisik maksimal, aktivitas katalase lebih rendah dibanding unit perlakuan lain. Dalam keadaan stres, aktivitas katalase berkurang karena komponen enzim katalase yang merupakan kompleks protein sudah dirusak oleh radikal bebas, karena target radikal bebas adalah merusak komponen senyawa protein, lipid dan karbohidrat. Radikal bebas menyerang pada gugus thiol yang terdapat pada komponen protein (Winarsi, 2007). Selain itu radikal bebas dapat menyebabkan inaktivasi enzim, dan kerusakan membran (Khairunanda, et al., 2014). Maka dari itu diperlukan antioksidan eksogen untuk membantu kerja dari antioksidan endogen.

Pengaruh Pemberian Ekstrak Daun Bambu Manggong pada Katalase Hati Tikus Putih Antioksidan eksogen yang digunakan dalam penelitian ini adalah senyawa yang terkandung dalam bambu manggong. Penentuan dosis yang digunakan dalam perlakuan diawali dengan pengujian toksisitas akut menggunakan beberapa dosis. Mortalitas atau kematian pada tikus dari berbagai dosis dilihat dari Tabel 1 hasilnya adalah 0, artinya tidak ada kematian hingga

\section{Aktivitas Katalase}

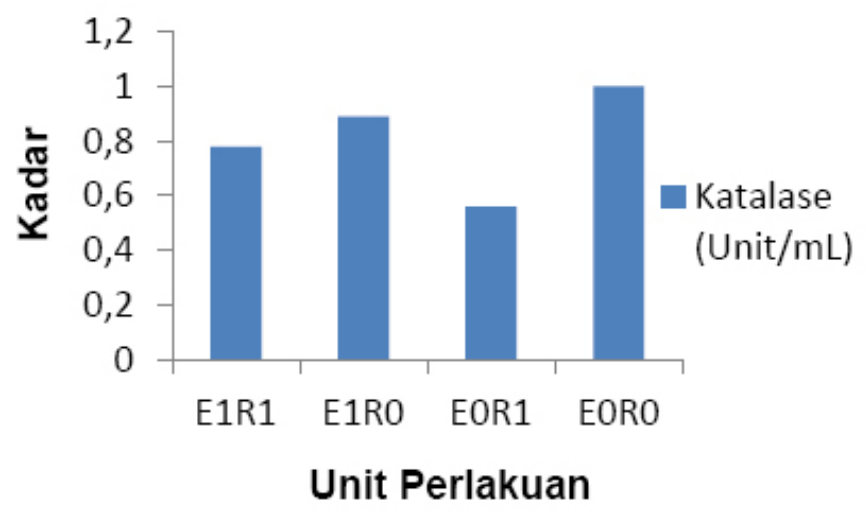

Gambar 1. Diagram aktivitas katalase hati tikus putih 
dosis terbesar sebeesar $20000 \mathrm{~g} / \mathrm{kgBB}$. Menurut Lu (2008) dosis ekstrak yang diberikan pada hewan uji lebih dari $15 \mathrm{~g} / \mathrm{kgBB}$ dan tidak menyebabkan kematian kemungkinan ekstrak tersebut tidak toksik bagi tubuh. Parameter lain dalam menentukan dosis akut selain kematian adalah berat badan dan tingkah laku. Berat badan terjadi peningkatan pada semua dosis kecuali pada dosis terbesar yaitu $20000 \mathrm{~g} / \mathrm{kgBB}$ yang mengalami penurunan.

Pada dosis terbesar ini, tingkah laku tikus sangat pasif dan nafsu makan menurun sehingga berat badan menjadi menurun. Keadaan stres memungkinkan penekanan nafsu makan sehingga berat badan menjadi menurun. Perbedaan kondisi berat badan dan tingkah laku ini juga didasari atas perbedaan kepekaan pada setiap individu hewan yang diuji coba (Guyton dan Hall, 2000). Karena tidak ditemukan mortalitas pada uji toksisitas, maka digunakan dosis $400 \mathrm{mg} / \mathrm{kgBB}$ (Lin et al., 2012) yang dilansir dapat mempengaruhi aktivitas katalase yang didapat dari penelitian sebelumnya yaitu pemberian ekstrak bambu dari famili yang sama dengan bambu manggong yakni famili Poaceae.

Aktivitas katalase pada hati tikus yang diberi ekstrak daun bambu manggong keadaannya stabil atau lebih tinggi dibandingkan tikus yang diberi aktivitas renang. Kelompok tikus yang diberi ekstrak daun bambu manggong yang diketahui mengandung senyawa antioksidan, seharusnya aktivitas katalasenya meningkat atau paling tidak menjadi stabil. Hal ini disebabkan senyawa yang terkandung dalam daun bambu manggong memiliki kemampuan antioksidan yang dapat membantu kerja enzim endogen dalam tubuh. Senyawa pada daun bambu manggong setelah

Tabel 1. Hasil uji toksisitas akut

\begin{tabular}{lll}
\hline Dosis $(\mathrm{mg} / \mathrm{kgBB})$ & Jumlah Tikus & Mortalitas \\
\hline 400 & 4 & $0 / 4$ \\
800 & 4 & $0 / 4$ \\
1250 & 4 & $0 / 4$ \\
2500 & 4 & $0 / 4$ \\
5000 & 4 & $0 / 4$ \\
10000 & 4 & $0 / 4$ \\
20000 & 4 & $0 / 4$ \\
\hline
\end{tabular}

diuji fitokimia positif mengandung senyawa-senyawa antioksidan seperti flavonoid, triterpenoid, alkaloid dan saponin. Menurut Takara (2002) dalam Sugito (2012) komponen senyawa fenol dapat menginduksi gen yang memproduksi enzim antioksidan, sehingga dapat mengurangi kerusakan enzim antioksidan akibat radikal bebas yang menyerang. Diketahui bahwa aktivitas dari gugus flavonoid yang tinggi dapat menstabilkan oksigen reaktif (Simanjuntak, 2012). Dalam Borra et al. (2006) senyawa flavonoid dapat meningkatkan regulasi gen yang memproduksi enzim, karena itu pemberian ekstrak daun bambu manggong seharusnya dapat menstabilkan aktivitas enzim katalase yang terdapat dalam tubuh.

Peranan senyawa alkaloid dalam antioksidan yaitu dapat melepaskan senyawa hidrogen dan berikatan dengan radikal bebas (Tiong et al., 2013). Kemudian senyawa terpenoid dan saponin mampu bertindak sebagai regulator metabolisme dan memainkan peran protektif sebagai antioksidan (Soetan, 2008). Berdasarkan pengujian fitokimia daun bambu manggong terdapat banyak senyawa antioksidan di dalamnya, tetapi tidak mampu mempengaruhi aktivitas katalase pada hati tikus dengan dosis yang digunakan dalam penelitian. Maka pemberian dosis perlu peningkatan agar dapat mempengaruhi aktivitas katalase. Interaksi Antara Pemberian Aktivitas Fisik Maksimal dan Ekstrak Daun Bambu Manggong pada Hati Tikus Putih Berdasarkan uji statistik dengan menggunakan ANAVA dua arah didapat hasil $p>0,05$ yang berarti tidak terdapat pengaruh terhadap aktivitas katalase hati tikus putih yang diberi aktivitas fisik maksimal berupa renang serta diberi ekstrak daun bambu manggong. Hal ini dimungkinkan karena 
terjadi penekanan pada aktivitas enzim lain yang terdapat pada hati (Lin et al., 2012). Seperti yang diketahui bahwa selain enzim katalase, terdapat enzim antioksidan endogen lain juga seperti superoksida dismutase dan glutation. Kerja dari enzim glutation sama halnya seperti enzim katalase yaitu mengubah hidrogen peroksida menjadi air dengan reaksi sebagai berikut:

$$
2 \mathrm{GSH}+\mathrm{H} 2 \mathrm{O} 2 \rightarrow \mathrm{GSSG}+2 \mathrm{H} 2 \mathrm{O}
$$

Selain adanya aktivitas dari enzim lain, pemberian ekstrak daun bambu manggong yang digunakan kemungkinan kurang optimal dalam menstabilkan aktivitas katalase dalam hati tikus. Dosis $400 \mathrm{mg} / \mathrm{kgB}$ pada ekstrak daun bambu manggong tidak mampu untuk mempengaruhi aktivitas katalase yang terdapat pada hati tikus, maka diperlukan penambahan dosis yang efektif untuk meningkatkan aktivitas katalase. Faktor lain juga dapat disebabkan perbedaan kepekaan setiap individu terhadap respon dari tiap perlakuan (Guyton dan Hall 2000), sehingga aktivitas katalase tidak dipengaruhi oleh aktivitas fisik maksimal dan pemberian ekstrak daun bambu manggong. Katalase mengkatalisis hidrogen peroksida (H2O2) menjadi air dan oksigen. Senyawa hidrogen peroksida terbentuk dari aktivitas enzim superoksida dismutase yang mengubah superoksida. Superoksida terbentuk akibat proses transpor elektron di mitokondria oleh sitokrom oksidase yang mereduksi O2 dengan menerima elektron dan reaksi dismutasi O2- yang dikatalisis oleh superoksida dismutase (Anatreira, 2009).

Struktur enzim katalase yang sebagian besar mengandung protein, dapat mudah rusak oleh beberapa faktor

Tabel 1. Hasil uji toksisitas akut

\begin{tabular}{lll}
\hline Dosis (mg/kgBB) & Jumlah Tikus & Mortalitas \\
\hline 400 & 4 & $0 / 4$ \\
800 & 4 & $0 / 4$ \\
1250 & 4 & $0 / 4$ \\
2500 & 4 & $0 / 4$ \\
5000 & 4 & $0 / 4$ \\
10000 & 4 & $0 / 4$ \\
20000 & 4 & $0 / 4$ \\
\hline
\end{tabular}

seperti suhu dan keasaman. Suhu yang panas dapat membuat protein dalam enzim mengalami denaturasi sehingga kerja enzim menjadi menurun. Selain suhu, aktivitas keasaman juga mempengaruhi kerja enzim. Enzim dapat bekerja baik pada $\mathrm{pH} \pm 7$ (Murray et al., 2009). Pada saat penelitian, kemungkinan keadaan lingkungan saat berlangsungnya pengukuran katalase kurang mendukung kerja enzim, sehingga didapat hasil yang kurang maksimal.

\section{KESIMPULAN}

1. Pada uji fitokimia daun bambu manggong didapatkan hasil positif terdapat senyawa alkaloid, flavonoid, triterpenoid dan saponin. Hasil negatif pada uji fenolat dan tanin.

\section{Ekstrak daun bambu manggong terindikasi bersifat non toksik.}

3. ktivitas fisik maksimal tidak mempengaruhi aktivitas katalase pada hati tikus putih.

4. Ekstrak daun bambu manggong tidak mempengaruhi aktivitas katalase pada hati tikus putih.

5. Interaksiantara aktivitas fisik maksimal dan ekstrak daun bambu manggong tidak mempengaruhi aktivitas katalase pada hati tikus putih. 


\section{DAFTAR PUSTAKA}

Aller, M. Angeles, et al. 2012. 『A Half Century (1961-2012) of Applying Microsurgery to Experimental Liver Search区. World J. Hepatol. 4; 7: 199-208.

Amelia, Gusmeta. 2006. Potensi Rumput Mutiara (Hedyotis corymbosa (L.) Lam.) Sebagai Antioksidan Alami. Bogor: Institut Pertanian Bogor.

Anatreira, R. Ayu. 2009. Perubahan Aktivitas Spesifik Katalase Jaringan Ginjal Tikus Percobaan yang Diinduksi Hipoksia Hipobarik Akut Berulang. Jakarta: Fakultas Kedokteran Universitas Indonesia.

Borra SC, Gambini J, GoMez-Cabrera MC, Sastr E J, Pallardo FV, Mann GE, et al. 2006. 『Genistein, A Soy Isoflavone, Up-Regulates Expression of Antioxidant Genes: Involvement of Estrogen Receptors ERK1/2, and NFLB囚. FASEB J. 20:1476-1481.

Cooper, K.H. 2000. Antioxidant Revolution. Tennessee: Thomas Nelson Publishers.

Dalimartha, Setiawan. 2008. Ensiklopedia Tanaman Obat Indonesia. Jakarta: Dinamika Media.

Guyton, Arthur C. dan John E. Hall. 2000. Textbook of Medical Physiology. Philadelphia: W B Saunders Co.

Halliwell, Barry dan John M.C. Gutteridge.1985. Free Radicals in Biology and Medicine. Inggris: Oxford University Press.

Harborne J.B. 1987. Metoda Fitokimia Penuntun Cara Modern Menganalisis Tumbuhan. Terjemahan Padmawinata K., Soediro I. Bandung: Institut Teknologi Bandung.

Harborne J.B. 1996. Metoda Fitokimia Penuntun Cara Modern Menganalisis Tumbuhan. Terjemahan Padmawinata K., Soediro I., Edisi II. Bandung: Institut Teknologi Bandung.

Hernani, Rahardjo M. 2005. Tanaman Berkhasiat Antioksidan. Jakarta: Penebar Swadaya.

Hernawati. 2009. Gambaran Efek Toksik Etanol Pada Sel Hati. Bandung: Universitas Pendidikan Indonesia.

Herwana, Elly. 2005. 『Efek Pemberian Minuman Stimulant Terhadap Kelelahan Pada Tikus囚. 24; 1.

Indrayana, Rony. 2008. Efek Antioksidan Ekstrak Etanol 70\% Daun Salam (Syzygium Polyanthum [Wight.] Walp.) pada Serum Darah Tikus Putih Jantan Galur Wistar yang Diinduksi Karbon Tetraklorida (CCl4). Surakarta: Universitas Muhammadiyah Surakarta.

Junqueira LC, Jose C, Robert OK. 1998. Histologi Dasar. Ed ke-8. Diterjemahkan Tambayong. Jakarta: EGC.

Kadarwati. 2006. Pengaruh Akar Ginseng (Wild Ginseng) dalam Ransum Mencit (Mus Musculus) Terhadap Jumlah Anak dan Pertumbuhan Anak dari Lahir Sampai dengan Sapih. Bogor: Insitut Pertanian Bogor.

Khairunanda, Nuryadi, dan Eko Suhartono, Triawanti. 2014. \Efek Pajanan Kadmium (Cd) Terhadap Aktivitas Katalase Darah Tikus Putih (Rattus Norvegicus)囚. Berkala Kedokteran. 10; 1: 25-30.

Lin, Zhao Lv, Xi Lin, Zhi hui Miao, Hong Xuan Guo, Jun An Hong Wang, Mei Ling Lei, Yue Pan dan Bo Lin Zhang. 2012. 『Antioxidant Activity of Bamboo Leaf Extract From Species Dendrocalamopsis oldhami冈. Scientific Research and Assay. 7; 44: 3789-3796.

Lopo, Yohanis. 2012. Identifikasi Jenis-Jenis Bambu (Bambusa sp.) Di Desa Tunfeu Kecamatan Nekamese Kabupaten Kupang (NTT). Kupang: Universitas PGRI NTT.

Lu, F.C. 1995. Toksikologi Dasar : Asas, Organ, Sasaran, dan Penilaian Resiko. Edisi 2. Jakarta: UI Press.

$\mathrm{Mu}$, Lingli, et al. 2007. 『Comparison of Neuroprotective Effects of Flavonoids, Terpenoids, and Their Combinations 
from Ginkgo biloba on Ischemia-Reperfusion-Injured Mice: Pharmaceutical Biology. 45; 9: 728-733.

Murray, Robert K., Daryl K., dan Victor W. Rodwell. 2009. Biokimia Harper. Edisi 27. Jakarta: EGC.

Nagaraja H.S. dan P. S. Jeganathan. 2003. Forced Swimming Stress Induced Alterations in Ingestive Behavior in Rats. Indian J Physiol Pharmacol. 47;1.

Octavia, D.R. 2009. Uji Aktivitas Penangkap Radikal Ekstra Petroleum Eter, Etil Asetat dan Etanol daun Binahong (Anredera cordifolia (Tenore) Steen) Dengan Metode DPPH (2,2-difenil-1- pikrihidrazil). Surakarta.

Ogunjinmi, A.A., H.M. Ijemoah, and A.A. Aiyeloja. 2009. Socio-Economic importance of Bamboo (Bambusa vulgaris) in Borgu Local Government Area of Niger State, Nigeria. Journal of Sustainable Development in Africa. 10; 4: 284-289.

Permana, Putra Adriyan. 2009. Efektivitas Pemberian Kedelai pada Tikus Putih (Rattus novergicus) Bunting dan Menyusui terhadap Pertumbuhan dan Kinerja Reproduksi Anak Tikus Betina. Bogor: Fakultas Kedokteran Hewan Institut Pertanian Bogor.

Prangdimurti, Endang, et al. 2006. \Aktivitas Antioksidan Ekstrak Daun Suji (Pleomele angustifolia N. E. Brown)】. Jurnal teknologi dan Industri Pangan. 17; 2.

Pratt DE, dan Hudson BJF. 1990. Food Antioxidant. London: Elsevier Applied Science. Prichett, K.R. \& B.F. Coming. 2004. Biology and Medicine of Rats. Institutional Animal Care and Use Committee.

Rusdi. 1990. Tetumbuhan Sebagai Sumber Bahan Obat. Padang: Pusat Penelitian Universitas Andalas.

Sherwood,L. 2010. Human Physiology From Cells to Systems 7th Edition. Canada: Brocks Cole.

Soetan, K.O. 2008. 『Pharmacological and other beneficial effects of anti- Nutritional factors in plants-a review African Journal of Biotechnology. 7; 25: 4713-4721.

Suckow MA, Weisbroth SH, Franklin CL. 2006. The Laboratory Rat. United Kingdom: Elsevier Academic Press.

Sugito. 2012. 『Aktivitas Antioksidan Biologis Sorgum dan Jewawut Serta Aplikasinya Pada Pencegahan Penyakit Degeneratif囚. Jurnal Pembangunan Manusia. 6; 1.

Sujarwo, Wawan, et al. 2010. 『Potensi Bambu Tali (Gigantochloa Apus J.A. \& J.H. Schult. Kurz) Sebagai Obat di Bali邓. Dalam Bul. Littro. 21; 2: 129 - 137.

Sujarwo, Wawan, et al.2010. "Inventarisasi Jenis-Jenis Bambu yang Berpotensi sebagai Obat di Kabupaten Karangasem Bali”. Bali: dalam Buletin Kebun Raya. 13; 1: 32-33.

Sutrisno, Bayu Tri, Yunianta. 2012. Antioxidant Potential and Antihepatotoxic Test of Aqueos Extract of Bamboo Leafs (Gigantochloa apus) in Wistar Strain Rats (Rattus Novergicus) Due Induced With Toxic Dose of Paracetamol. Malang.

Soeatmaji, D.W. 1998. \Peran Stres Oksidatif dalam Patogenesis Angiopati Mikro dan Makro DM】. Medica. 5; 24 : 318- 325.

Tukan, Maria Florentina. 2014. Kadar Antioksidan Enzimatik Katalase Pada Abortus Inkomplit Lebih Rendah Dibandingkan Dengan Kehamilan Normal Trimester Pertama. Denpasar: Universitas Udayana.

Utomo, Astika Widy, dan Noor Wijayahadi. 2008. Uji Toksisitas Akut Ekstrak Alkohol Daun Jati Belanda (Guazuma Ulmifolia Lamk) Pada Tikus Wistar. Semarang: Fakultas Kedokteran Universitas Diponegoro. V alko, M. 2007. Free radicals and antioxidants in normal physiological functions and human disease. Elsevier. 
Wang, Jin et al. 2012. 『TLC Screening for Antioxidant Activity of Extracts from Fifteen Bamboo Species and Identification of Antioxidant Flavone Glycosides from Leaves of Bambusa. textilis McClure区. Molecules. 17: 12297-12311.

Widjaja, E.A. 2001. Identifikasi Jenis-jenis Bambu di Jawa, Bogor. Bogor: Pusat Penelitian dan Pengembangan Biologi LIPI.

Winarsi, Hery. 2007. Antioksidan Alami dan Radikal Bebas. Yogyakarta: Kanisius.

Zainuri, Masagus dan Septelia I.W. 2012. \Aktivitas Spesifik Manganese Superoxide Dismutase (MnSOD) dan Katalase Pada Hati Tikus yang Diinduksi Hipoksia Sistemik: Hubungannya dengan Kerusakan Oksidati円囚. Media Litbang Kesehatan. 22; 2.

Zakaria, R., F. 1996. 囚Peranan Zat Gizi dalam Sistem Kekebalan Tubuh囚. Dalam Bul. Teknol. dan Industri Pangan. $7 ; 3: 75-81$. 